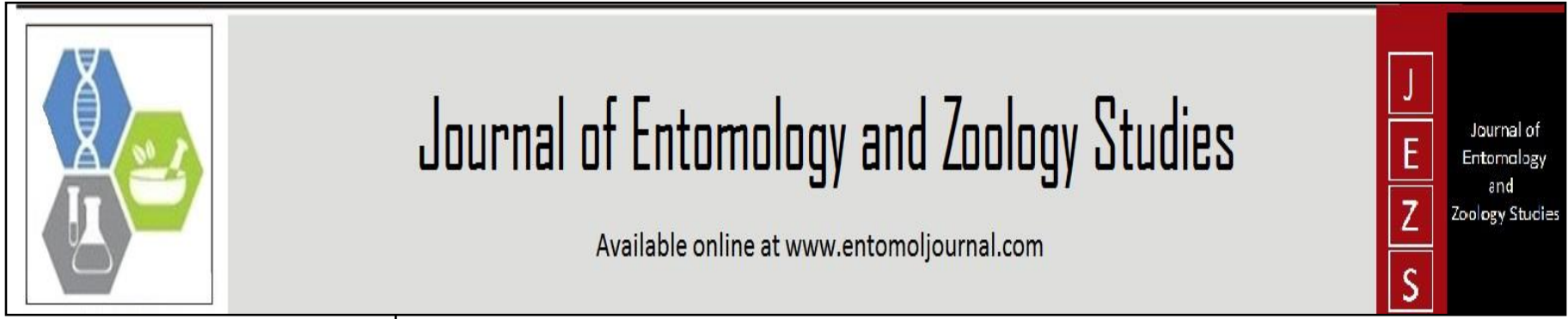

E-ISSN: 2320-7078

P-ISSN: 2349-6800

www.entomoljournal.com JEZS 2021; 9(4): 207-209 (C) $2021 \mathrm{JEZS}$

Received: 04-05-2021

Accepted: 06-06-2021

R Raja Rishi

Forest Protection Division,

Institute of Wood Science and

Technology, Bengaluru,

Karnataka, India

R Sundararaj

Forest Protection Division,

Institute of Wood Science and

Technology, Bengaluru,

Karnataka, India
Corresponding Author:

R Raja Rishi

Forest Protection Division,

Institute of Wood Science and

Technology, Bengaluru,

Karnataka, India

\section{Incidence of bark feeding borer, Indarbela quadrinotata Walker (Lepidoptera: Cossidae) on Sonneratia apetala in the Mangroves of Maharashtra, India}

\section{R Raja Rishi and R Sundararaj}

DOI: https://doi.org/10.22271/j.ento.2021.v9.i4c.8756

Abstract

The bark feeding caterpillar Indarbela quadrinotata is a polyphagous insect, which attack different tree species of forestry importance, horticultural plants and occasionally the mangroves. Though this pest is considered as minor pest, it occasionally causes outbreak if the conditions are favourable. This was observed causing damage to the mangrove plant species particularly on Sonneratia apetala in the mangroves of Airoli and Vashi creek of Thane district of Maharashtra in the year 2018. This is the first incidence of its infestation on $S$. apetala in this region. The intensity of the pest incidence was spordic to moderate level and the percentage of attack was $20-35 \%$. The entomopathogenic fungus Beauveria bassiana spore solution at the concentration of $2.4 \times 10^{8}$ Spores $/ \mathrm{ml}$ can control the pest.

Keywords: Sonneratia apetala, Indarbela quadrinotata, mangrove, polyphagous, infestation

\section{Introduction}

Indian mangroves which comprise of 3.3 percent in the global cover and distributed along the maritime states, except Lakshadweep, covering an area of about $4921 \mathrm{sq} . \mathrm{km}$ along the 7,500 $\mathrm{km}$ long Indian coastline ${ }^{[1]}$. Mangroves are an important component ecologically in the coastal ecosystem, and are under severe threat globally because of different causes ${ }^{[2]}$. The contribution towards ecological services by the mangroves is vital [3]. Indian mangrove ecosystems are having the biological diversity of 4,011 species which includes $23 \%$ plants and remaining are different species of animals ${ }^{[4]}$. There are about 55 mangrove species belongs to 22 genera under 18 families have been recorded in the Indian Ocean region ${ }^{[5]}$. Among the 52 creeks present across the $720 \mathrm{~km}$ coastline of Maharashtra State 18 are considered as major ones and have developed mangrove habitats ${ }^{[6]}$. In Greater Mumbai, the density of mangrove trees is the highest in Thane Creek $\left(30\right.$ trees $\left./ 25 \mathrm{~m}^{2}\right)$ followed by other creeks ( 9.5 to 28.5 trees/ $\left.25 \mathrm{~m}^{2}\right)^{[7]}$. Among the mangorve species available in Maharashtra, Avicennia marina, A. officinalis, Sonneratia alba and $S$. apetala are the dominant species grown in Airoli and Vashi creek of Thane district. Mangrove species are often infested by serveral insect pests. During the surveys conducted to assess the insect pest problems of mangrove species in Airoli and Vashi creek revealed the infestation of the bark feeding borer Indarbela quadrinotata Walker on $S$. apetala. It is a primitive lepidopteran pest belonging to the family Cossidae. It is a serious pest of a large number of plant types throughout Asia ${ }^{[8]}$. About 422 insects belongs to 41 families which includes 212 belongs to the order Lepidoptera and 69 Hemipterans, in addition to the checklist of insects of Indian mangrove ecosystem reported earlier during 2008 by different authors ${ }^{[9]}$. Few insects species were reported infesting the mangroves in Pitchavaram mangroves, South coast of India, and the predominant insect species are the leaf mining moth (Phyllocnistis sp.), leaf gall species (Stephaniella falcaria, Monolepta sp.), caterpillars (Dasychira sp., Capua endocypha and Odites spp.) and scale insects (Aspidiotus destructor ${ }^{[10]}$.

\section{Material and Methods}

During the year 2018 periodic surveys were conducted to assess the insect pest problems on the mangroves species of Airoli and Vashi creek of Thane district of Maharashtra (Airoli Natural mangroves -N 19 14'76.5” E 72 98'43.9”, Ghansoli Plantation- N 19 $11^{\prime} 50.9^{\prime \prime}$ E $72^{\circ}$ 
99'17.3"). The intensity of attack was also assessed by the level of incidence of the insect pests and percentage of the damage/extent of damage caused. Based on the incidence and intensity of insect pest attack calculation was made as per the prescribed methods of assessment of insect pest incidence ${ }^{[11]}$.

\section{Result and Discussion}

The regular insect pest surveys conducted to observe the pest problems in the mangroves of Airoli and Vashi creek of Thane district of Maharashtra during the year 2018 revealed that the first time incidence of infestation of the bark feeding borer I. quadrinotata on S. apetala in this region. The young plants of $S$. apetala were heavily infested by the bark feeding borer (Fig 1 A \& B). With the range of 20 to 35 percent of plants were affected by this pest with moderate intensity of attack. The pale to dark brownish colour larvae feed on the bark surrounding the tunnel mouth under a sleeve, which made of frass and excreta of the larva webbed together, which extend from the tunnel opening (Fig. $1 \mathrm{C}$ ). This pest is the most common and widely distributed in different tree species of horticultural and forestry importance. The life cycle of this insect has been worked out on various hosts by the researchers. Life cycle is annual with one generation per year. Adults start emerging during May to July. Adult moth is yellowish brown with brown markings on the forewings (Fig $1 \mathrm{E})$. Females oviposit under loose bark in clusters in early June to July. Eggs hatch in 15-25 days. Larvae that hatch out initially feed on the bark and subsequently bore into the trunk
(Fig 1 D). The larval period lasts for 9 -10 months. Pupation occurs within the larval tunnel, with the cephalic end of the pupa slightly protruding outside. The pupal period lasts for about 15-25 days. The tunneling caused by the larvae which causes weak points on the trees and subsiquently the breakages occur which leads to the reduction in growth rate of the plants. In some incidence this breaking also providing entry points for secondary infestations like fungal pathogens and shelter for other pests.

The biology and management of I. quadrinotata was studied on different horticultural species by the researchers ${ }^{[12]}$. The method of management by spraying of the aqueous fungal solution of Beauveria bassiana at a concentration of $2.4 \times 10^{8}$ Spores/ml on the thick frass mat can control the pest effectively. Using of microbial biopesticides for the control of different inscet pests has been studied by many workers. $B$. bassiana is one of the important entomopathogenic fungus which plays an important role in the regulation of pest population ${ }^{[13]}$. It was effective on the Casuarina bark feeding borer I. quadrinotata ${ }^{[14]}$. Different fungal pathogens including $B$. bassiana were tested against the coffee berry borer Hypothenemus hampei and reported B. bassiana is a potential microbial agent suitable for controling the pest $H$. hampei ${ }^{[15]}$. Pathogenicity of the fungus $B$. bassiana was tested on $S$. malabaricus, a pest of Teak in laboratory condition and reported effective ${ }^{[16]}$. B. bassiana was found effective in controling I. quadrinotata on Paraserianthes falcataria $^{[17]}$.
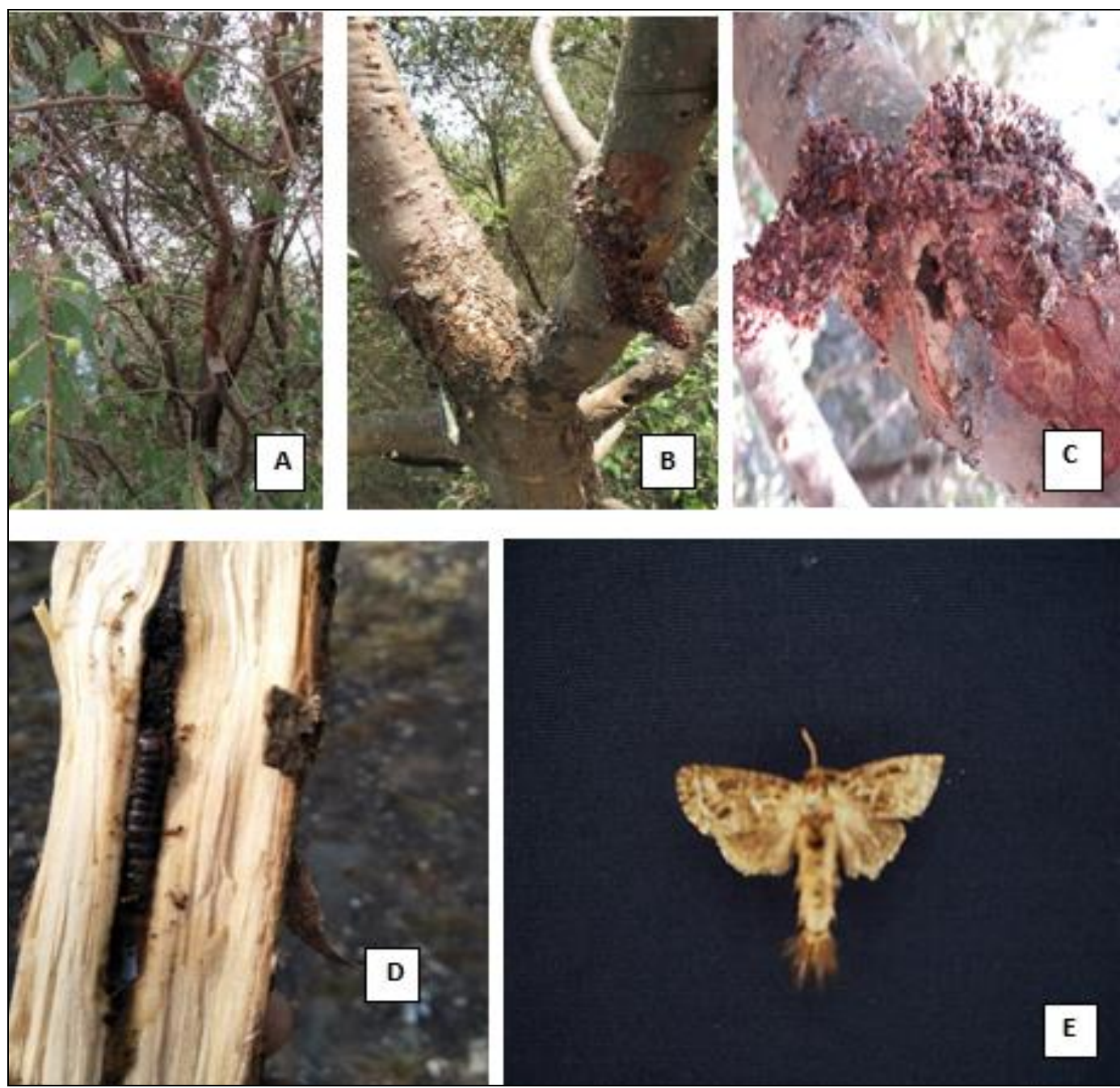

Fig 1: Indarbela quadrinotata attack on Sonneratia apetala (A) \& (B) Stem borer attack on the young plants of S. apetala (C) Frass mat near the tunnel opening (D) Grown up I. quadrinotata larva inside the young stem (E) Adult moth of I. quadrinotata 


\section{Conclusion}

The present study confirms that I. quadrinotata is a potential and harmful insect pest of $S$. apetala. The intensity of the pest incidence was sporadic to moderate level and the percentage of attack was $20-35 \%$ in the study area. Eco-friendly approaches such as using entomopathogenic fungi as biological control is considered as the best alternatives. There is a growing interest in the use of entomopathogens for biological control, since they are naturally occurring and environmentally safe. Identification and controling the pest in the initial stage is the best way to tackle this pest in the mangroves. Further indepth research is required study the pest in the mangroves, their host range and the effectiveness through ecofriendly management in field condition.

\section{Acknowledgement}

The authors are thankful to the Director, Institute of Wood Science and Technology, Bengaluru for the facilities provided to carry out the laboratory work. We are thankful to the Executive Director, Mangrove Cell, Maharashtra Forest Department for given permission and the cooperation rendered during our field visits.

\section{References}

1. Forest Survey of India. State Forest Report. Ministry of Environment and Forest, Mangrove cover. 2017, 55-61.

2. Hai NT, Dell B, Phuong VT, Harper RJ. Towards a more robust approach for the restoration of mangroves in Vietnam. Ann. For. Sci 2020;77(1):18.

3. Kumari P, Singh JK, Pathak B. Potential contribution of multifunctional mangrove resources and its conservation. In: Biotechnological utilization of mangrove resources. Academic Press, 2020, 1-26.

4. Bhatt JR, Kathiresan K. Biodiversity of mangrove ecosystems in India. Published in Book "Towards conservation and management of mangrove ecosystems in India" (Eds.) Bhatt J.R., Macintosh DJ, Nayar TS, Pandey CN, Nilaratna BP. Published by the International Union for Conservation of Nature and Natural Resources. Printed at St. Joseph's Press, Thiruvananthapuram, Kerala., India 2011, 278.

5. Singh AK, Abubakar A, Dinesh Kumar, Sarkar UK. Status, Biodiversity and distribution of mangroves in India; An overview. Proceedings of International day for Biological diversity - Marine Biodiversity- 22 May 2012. Uttar Pradesh State Biodiversity Board 2012, 5967.

6. Shree Bhagwan. Status of mangrove conservation and management in Maharashtra. Mangroves of India: their biology and uses, ZSI publication, Kolkata (Eds.) Bhatt J.R, Ramakrishna, Sanjappa M, Remadevi OK, Nilaratna BP, Venkataraman K 2013, 79-92.

7. Vijay V, Biradar RS, Inamdar AB, Deshmukhe G, Baji S, Pikle M. Mangrove mapping and change detection around Mumbai (Bombay) using remotely sensed data. Indian Journal of Marine Sciences 2005;34:310-315.

8. Beeson CFC. The Ecology and Control of Forest Insects of India and the neighbouring Countries. Govt. of India $1941,767$.

9. Shwetha V, Raja Rishi R, Sundararaj R, Sunayana TP. Check-list of entomofauna of mangrove ecosystem in India. International J. Science and Nature 2019;10(4):159-172.

10. Kathiresan K. Insect foliovory in mangroves. Ind. J. Mar.
Sci, 2003; 32(3):237-239.

11. Geroge Mathew. Biology and ecology of the teak trunk borer Cossus cadambae Moore and its possible control. KFRI Research Report 1990;68:41.

12. Satyanaryana C, Arunakumara KT. Biology and management of guava bark eating caterpillar, Indarbela tetraonis Moore. Agric. Sci. Digest 2016;36(3):197-201.

13. Ferron P. Pest control by the fungi Beauveria and Metarhizium. In: Microbial Control of Insects and Mites. Burges HD, ed. Academic Press, New York, USA 1981, 465-482.

14. Balu A, Sasidharan KR, Raja Rishi R. A new record of the promising biocontrol agent Beauveria bassiana on the bark feeder/stem borer, Indarbela quadrinotata. Sylva plus 1998;7:1.

15. De La RW, Alatorre R, Trujillo J, Barrera JF. Virulence of Beauveria bassiana (Deuteromycetes) strains against the coffee berry borer Biological and microbial control. J. Eco. Ent 1997;90(6):1534-1538.

16. Mohamed Ali MI, Mathew G. Occurrence of Beauveria bassiana (Balsamo) Vuill. On sapling borer Sahyadrassus malabaricus Moore (Lepi. Hepalidae) in Kerala, India. Current Science 1989;58(16):931-932.

17. Mathew G. Management of the bark caterpillar Indarbela quadrinotata in forest plantations of Paraserianthes falcataria. KFRI Research Report 122. Kerala Forest Research Institute, Peechi 1997, 24. 